\begin{tabular}{|c|c|}
\hline 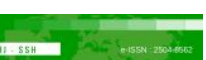 & Malaysian Journal of Social Sciences and Humanities (MJSSH) \\
\hline Malaysian Journal of & Volume 6, Issue 4, April 2021 \\
\hline (mJ-ssH) & e-ISSN : 2504-8562 \\
\hline & $\begin{array}{l}\text { Journal home page: } \\
\text { www.msocialsciences.com }\end{array}$ \\
\hline
\end{tabular}

\title{
The Translation of Qur'an Non-Existent Cultural Elements in Malay Culture: An Analysis on Borrowing Approach
}

\author{
Arnida A. Bakar ${ }^{1}$, Sulhah Ramli1 \\ 1Faculty of Major Language Studies, Universiti Sains Islam Malaysia (USIM) \\ Correspondence: Arnida A. Bakar (arnida@usim.edu.my)
}

\begin{abstract}
Many translation scholars have proposed various approaches when dealing with culture-specific items. It shows that to achieve a good quality and successful translation work, suitable and functional translation approach should be applied by the translator. Borrowing is one of the approaches applied in various texts' genre such as sacred text which has culture-specific items. It becomes frequently used in translating word with no equivalent in target language. However, it resulted in some of translations which have applied this kind of approach did not supply adequate meaning and fallout the irrelevant text towards readership. The reason is that borrowing approach stands alone without providing compensation strategies. Therefore, this present article investigates the functionality of borrowing approach in translating Qur'an non-existent cultural elements in Malay culture. This study is qualitative, and the data are analysed descriptively using document analysis by adopting Relevance Theory initiated by Sperber and Wilson (1986). It is suggested that the relevancy of translated text can be achieved not only through borrowing as an approach, but at the same time providing adequate meaning by means of compensation strategies. Thus, the study assumes that the less the effort processing is produced to understand the meaning, the higher the contextual effect of meaning is sufficiently provided. On the other hand, if the effort processing is less produced and the contextual effect is highly provided, the optimum relevancy of translated text can be achieved. It is concluded that the combination of borrowing approach and compensation strategies can help better understanding the meaning of non-existent religious cultural items in Malay culture.
\end{abstract}

Keywords: Translation approach, non-existent cultural elements, target culture, unseen elements, compensation strategies

\section{Introduction}

Translation is a means of transferring knowledge from a source text to a target text. Not only language is involved, but also cultural element which is an important component needs to be considered by a translator when dealing with the source text. In order to transfer message of the source text effectively and successfully, translation approach and procedure are essential to achieve the target. Furthermore, many translation scholars have proposed various approaches when dealing with culture-specific items. It shows that to achieve a good quality and successful translation work, suitable and functional translation approach should be applied by the translator. 


\section{Literature Review}

\section{The Translation of Holy Qur'an}

One of the most noticeable developments of Quranic exegesis in the Muslim world is the upsurge of the translations of the Holy Qur'an in the twentieth century. The Index Translationum (http://unesco.org/culture/xtrans/) statistics indicate that the Holy Qur'an has been translated into more than twenty languages, including major European languages and Asian languages (Abobaker Ali \& Sharifah Fazliyaton, 2014:96). Qadhi (1999:348) argues that given the different languages in the world, it has become necessary to translate this sacred text from Arabic into other languages so that more readers can access and benefit from the translation of the Holy Qur'an.

There are two major types of The Qur'an translation; the first type is semantic translation, and the second type is that which provides a communicative translation (Hussein Abdul-Raof, 2001: 21). Translation is considered as means of communication between nations and bridging the linguistic and cultural gaps among them. Thus, culture-specific religious words and concepts found in the Qur'an need to be illuminated; for instance, footnote as a compensation strategy in order to avoid unclear meaning towards target culture.

\section{Translation Procedure: Borrowing Approach}

Translation procedures are methods applied by translators when they formulate an equivalence for the purpose of transferring elements of meaning from the Source Text (ST) to the Target Text (TT) (Roswani Siregar, 2016: 52). Jean Paul Vinay and Jean Darbelnet in the 1950s came up with seven procedures of translation and as many ways to attain equivalence. Vinay and Darbelnet (1958/1995) proposed seven methods or procedures, they are borrowing, calque, literal, transposition, modulation, equivalence and adaptation. Their view was that if literal translation or direct translation was impossible, then the translator would have to resort to what they termed oblique translation. Oblique translation is another term for free translation where the translator exercises his/her freedom to attain equivalence. Borrowingdirect translation- is the simplest of all translation methods. It is used to overcome the lacuna (missing gap or part for instance, language and culture found in the source text and translated into the target text). In order to introduce the flavor of the source language culture into a translation, foreign terms may be used such as Arabic words like abaya and henna or Russian words like tequila and tortillas.

\section{Translation and Culture: The Qur'an Non-Existent Cultural Elements in Malay Culture}

Newmark defines culture as the way of life and its manifestations that are peculiar to a community that uses a particular language as its means of expression (1988: 94). Frequently where there is cultural focus, there is a translation problem due to the cultural gap or distance between the source and target languages.

Eugene Nida (1964:55) proposes five groups of classification of cultural references which are: 1) material-related to everyday objects. 2) ecological- related to differences in the places, weather, flora, fauna, etc. 3) social-related to social organization and its artistic manifestations in the Arts or Literature and History. 4) religious- include ritualized and ideological manifestations. 5) linguistic-refers to attitudes and conversational cues (according to Hatim, 1997)-ways of thinking and speaking which typify particular groups of text users.

Meanwhile, Newmark (1988: 95) discusses the translation of foreign cultural words in the narrow sense. By adapting Nida's classification of cultural references, Newmark categorizes them into five types which are 1) ecology-flora, fauna, winds, plains and hills. 2) material culture (artifacts). 3) social culture-work and leisure. 4) Organizations, customs, activities, procedures, concepts. 5) Gestures and habits.

In translating cultural elements in The Qur'an, Hussein Abdul-Raof (2001) urged the need of providing footnotes in explaining them. Among those elements are: 1) historical facts 2) geographical facts 3 ) ecological facts 4) cultural expressions 5) religious concepts. 
For the purpose of this research, The Qur'an non-existent cultural elements in Malay culture which are related to unseen (غيبيات) and faith-related elements (المعتقدات) are selected and both of them refer to the religious concepts (Arnida, Sulhah \& Akmal Khuzairy, 2019).

\section{Relevance Theory}

Relevance Theory (RT) in communication was introduced by Sperber and Wilson in 1986. RT focuses on the appropriateness or relevance of a communication can be achieved and understood clearly and easily by the speaker and the listener. RT emphasizes two things in the consideration and evaluation of optimal speech relevance, namely the cognitive effect (CE) of the listener on the information and the level of effort to process the information, so that the listener can make inferences about the information easily.

Meanwhile, RT in translation context concerns about the role of translator and the translated text. This is to ensure that the translated text can be easily understood by the target reader. The translator should understand the context underlying the translated text including the social, psychological and cultural background of the target reader (Majdi 2009: 143; Ainon et al. 2008: 74-76).

There are two main principles emphasized in RT to determine the relevance of a translated text, namely (i) contextual effect (CE) and (ii) processing effort (PE) (Sperber et al. 1986: 125; Cutting 2002: 43; Siti Hajar 2010: 60).

In addition, Muhammad Fauzi (2002) highlights that the speaker (in translation; author of the original text) should ensure that what is being said is really relevant and easy to understand by the listener (in translation; reader of the translated text). Furthermore, Majdi (2009) states that translators should know the social, political, economic contexts of the target language. By considering all these elements, the translated text will be closer and more natural to the target reader.

\section{Methodology}

This study is qualitative, and the data are analyzed descriptively using document analysis. The study selected Malay Qur'an Translation; Al-Kalam published by Al-Hidayah House of Qur'an Sdn Bhd as the purpose of translation reference. Non-existent cultural elements in Malay culture were selected which only related to unseen (غيبيات) and faith (معتقدات). The focus is on the borrowing approach applied by the translator in translating those elements.

The data were analyzed using Relevance Theory (RT) by Sperber \& Wilson (1986). The main purpose of RT is to identify the appropriateness of a given translation in the target language. The theory is a method that will help this research to see the extent to which the translation is appropriate to the context, meaning and usage. The relevancy of translated text can be achieved not only through borrowing as an approach, but at the same time providing adequate meaning by means of compensation strategy.

Figure 1: Methodology of the Study

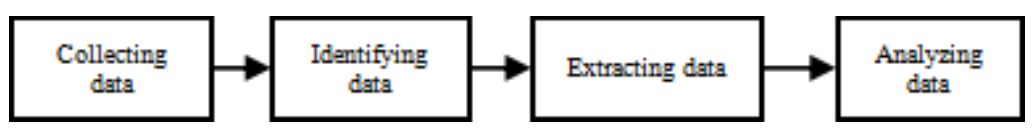

The study adopted thematic analysis for conducting this research (Braun \& Clarke, 2006). The first step is collecting data of cultural elements in the Qur'an. Secondly, identifying the data which are related to non-existent cultural elements in Malay culture. The third step is extracting only the unseen and faith- 
related cultural elements with borrowing approach applied by the translator in Malay language. The final step is analyzing the selected data using Relevance Theory (RT).

\section{Theoretical Framework}

Relevance theory refers to two principles of relevance: A Cognitive Principle (that human cognition is geared to the maximization of relevance), and a Communicative Principle (that utterances create expectations of optimal relevance). An utterance is measured by analyzing both the contextual effect and effort processing for the purpose of achieving the optimal relevance in communication between speaker and listener (Sperber \& Wilson, 1986). According to Sperber and Wilson, both argue that the appropriateness or relevance of a communication can be achieved when speech can be easily understood by the speaker or listener (Cutting 2002: 43). Figure 2 demonstrates Relevance Theory (RT) in communication.

Figure 2: RT in communication

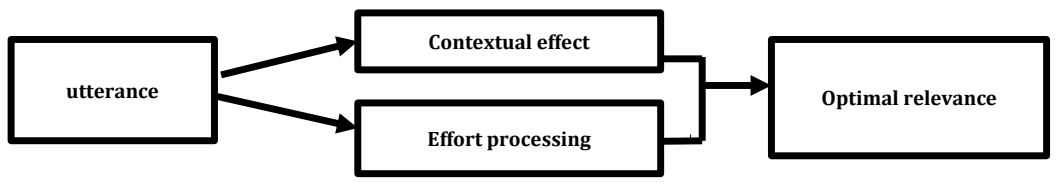

Meanwhile in pragmatic analysis, Sulhah (2013) adopted RT in conducting her research related to semantic translation. This current study adopts RT framework of Sulhah (2013) in analyzing the selected cultural elements and its translations into Malay language.

Figure 3: RT in semantic translation

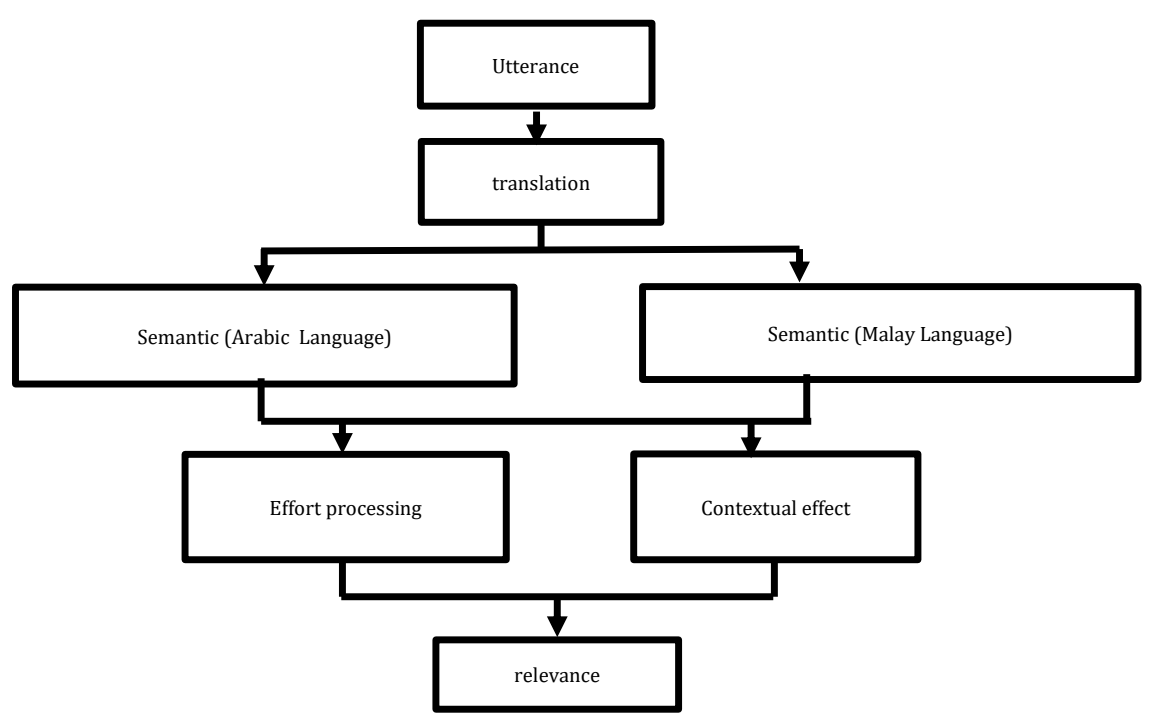

\section{Conceptual Framework}

The flow of analysis procedure starts with extracting the non-existent cultural elements in Malay culture in the source text, The Qur'an. Then, the selected translated text which is Malay Qur'an translation is referred to uncover the translation of only the chosen elements; unseen and faith-related elements which do not exist in Malay culture. The limitation is on the borrowing approach either with or without compensation strategy for the purpose of the discussion. In order to investigate whether the translated 
text achieved the optimal relevance or not, Relevance Theory (RT) is applied by measuring the contextual effect (CE) and effort processing (EF).

Thus, this study measures the translated text by means of borrowing approach (successfully achieved or not) by these two components of RT. This leads to the effective and functional translation of those elements or vice versa towards Malay culture.

Figure 4 shows Relevance Theory of the current study.

Figure 4: RT of the current study

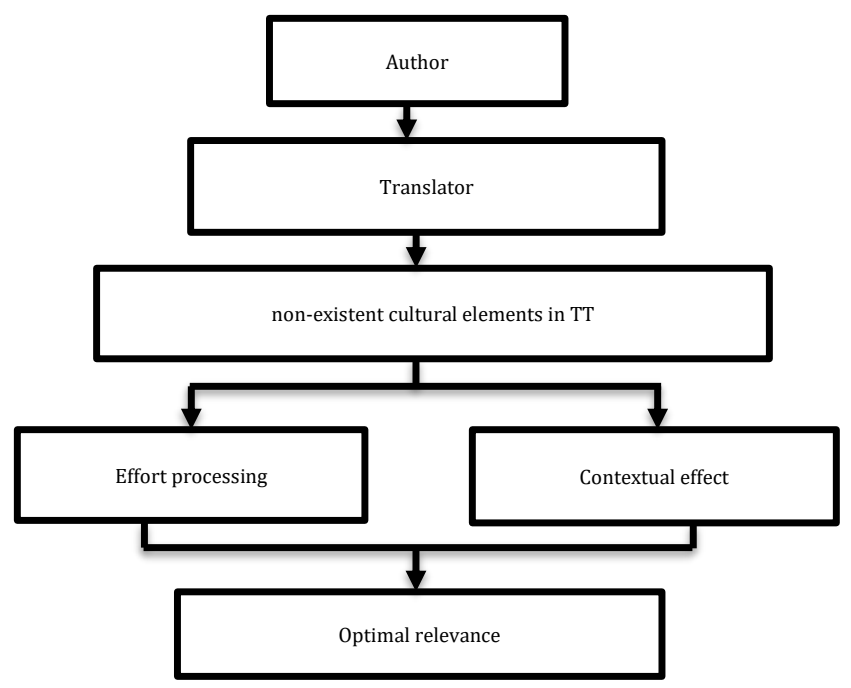

\section{Result \& Discussion}

The data for analysis include source text in Arabic and target text in Malay with its compensated meanings. These compensated meanings are provided as footnote for further explanation. Table 1 below contains a selection of cultural elements which are not exist in Malay culture and its translations in Malay language. Furthermore, only the borrowing approach is selected for the purpose of discussion. These three examples represent the unseen elements (العناصر الثقافية المتعلقة بالغييبات) as stated below:

Table 1: Samples of Unseen Element

\begin{tabular}{|c|c|c|}
\hline Source Text (ST) & Target Text (TT) & Compensation Strategy \\
\hline 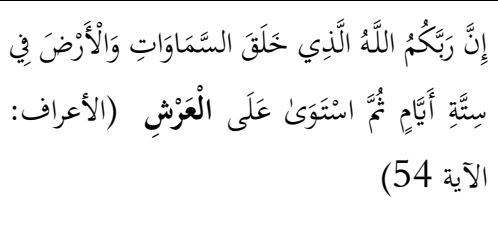 & $\begin{array}{l}\text { Sesungguhnya Tuhan kamu } \\
\text { ialah Allah yang telah } \\
\text { menciptakan langit dan bumi } \\
\text { dalam enam masa, lalu Dia } \\
\text { bersemayam di atas Arasy. (al- } \\
\text { A'raf: } 54 \text { ) }\end{array}$ & $\begin{array}{l}\text { Footnote: Bersemayam di atas } \\
\text { Arasy ialah salah satu sifat Allah } \\
\text { yang wajib kita imani, sesuai } \\
\text { dengan kebesaran Allah dan } \\
\text { kesucian-Nya }\end{array}$ \\
\hline 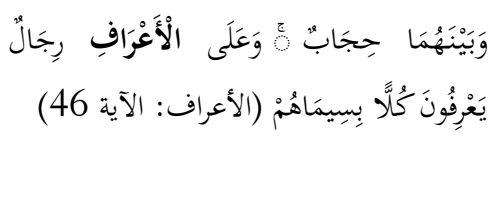 & $\begin{array}{l}\text { Dan di antara keduanya } \\
\text { (penghuni syurga dan neraka) } \\
\text { ada tembok pemisah; dan di atas } \\
\text { Al-A'raf itu ada orang yang } \\
\text { masing-masing mengenali dari }\end{array}$ & $\begin{array}{l}\text { Footnote: al-A'raf, ertinya; tempat } \\
\text { yang tertinggi di antara syurga dan } \\
\text { neraka }\end{array}$ \\
\hline
\end{tabular}


dua golongan itu dengan tanda-

tanda mereka. (al-A'raf: 46).

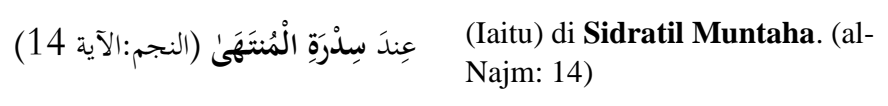

i. Sample 1 - ST الْعَرْنِ TT Arasy
Footnote: Sidratul Muntaha iaitu tempat yang paling tinggi di atas langit yang ke-7, yang telah dikunjungi Nabi Sallallahu 'alaihi wasallam ketika Mikraj

- Translation approach: (Borrowing + footnote: Bersemayam di atas Arasy ialah salah satu sifat Allah yang wajib kita imani, sesuai dengan kebesaran Allah dan kesucian-Nya).

- Meaning: The word "Arasy" means the (Divine) Throne (https://www.almaany.com/ar/dict/ar-

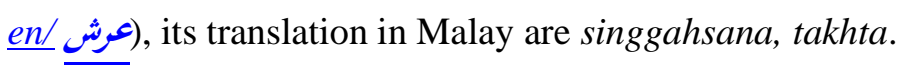

- The footnote of Data 1 did not adequately provide the meaning of Arasy in Malay language.

Based on RT, the study found that the contextual effect is low, and the processing effort is high. This is because the meaning is not clearly understood thus, effects the cognitive process of getting the idea of this unseen element in Malay culture. Meanwhile, the effort to process the meaning is highly needed in this translation as no adequate meaning is given. In addition, the information needs to be processed in order to understand the meaning of Arasy in Malay language.

In conclusion, the borrowing approach used to translate Arasy cannot stand by itself, thus, it needs compensation strategy. However, the explanation given in the footnote is not adequate enough as to make the reader understand the meaning properly. This resulted in the optimal relevance of the translated text is not successfully achieved.

\section{ii. Sample 2 - ST الْغَعْرَافِ TT Al-A'raf}

- Translation approach: (Borrowing + footnote: al-A 'raf ertinya tempat yang tertinggi di antara syurga dan neraka).

- Meaning: The word "al-A'raf" means the Heights which is situated between Paradise and Hell (https://www.almaany.com/ar/dict/ar-en/الأعراف), its translation in Malay are tinggi, puncak, tempat paling tinggi di antara syurga dan neraka.

- The footnote of Data 2 adequately provides the meaning of al-A'raf in Malay language.

Based on RT, the study found that the contextual effect is high, and the processing effort is low. This is because the meaning is clearly understood thus, effects the smooth cognitive process of getting the idea of this unseen element in Malay culture. Meanwhile, the effort to process the meaning is at low limit for this translation as adequate meaning is given. In addition, the information is easily processed and at immediate rate for the target reader to understand the meaning of al-A'raf in Malay language.

In conclusion, it is suggested that not only the borrowing approach is used to translate $a l-A$ 'raf, but also should be provided with compensation strategy. The reason is to get the idea of the meaning properly 
and adequately, specifically this kind of unseen element. This resulted in the optimal relevance of the translated text is successfully achieved.

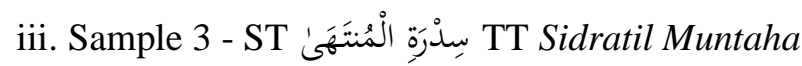

- Translation approach: (Borrowing + footnote: Sidratul Muntaha iaitu tempat yang paling tinggi di atas langit yang ke-7, yang telah dikunjungi Nabi Sallallahu 'alaihi wasallam ketika Mikraj).

- Meaning: "Sidratil Muntaha" means the Lote Tree of the Utmost Boundary, beyond the 7th heaven, none can pass beyond it except the Prophet (https://www.almaany.com/ar/dict/aren/ (سلدرة المنتهى (1ts translation in Malay is pohon besar di dalam syurga yang berada di langit ke tujuh, tiada yang melepasi tempat ini melainkan Nabi Muhammad SAW.

- The footnote of Data 3 provides partial adequate meaning of Sidratil Muntaha in Malay language.

Based on RT, the study found that the contextual effect is high, and the processing effort is low. Although some information of Sidratul muntaha is not fully stated in the footnote, but the meaning can still be understood. This leads to the minimum struggle of the cognitive process in getting the idea of this unseen element in Malay culture. Meanwhile, the moderate effort to process the meaning is still at low limit although the footnote provides partial adequate meaning. The target reader still has the idea of the meaning given in Malay language.

In conclusion, the study found that both borrowing approach and compensation strategy assist deeper understanding of the unseen element; Sidratul Muntaha in Malay culture. However, by providing the adequate meaning of this translated element will help the target reader understand more clearly and effectively. This resulted in the optimal relevance of the translated text is successfully achieved.

The table 2 below represents the three examples of faith-related cultural elements ( العناصر الثقافية المتعلقة (بالمعتقدات which do not exist in Malay culture and its translations.

Table 2: Samples Faith-Related Cultural Element

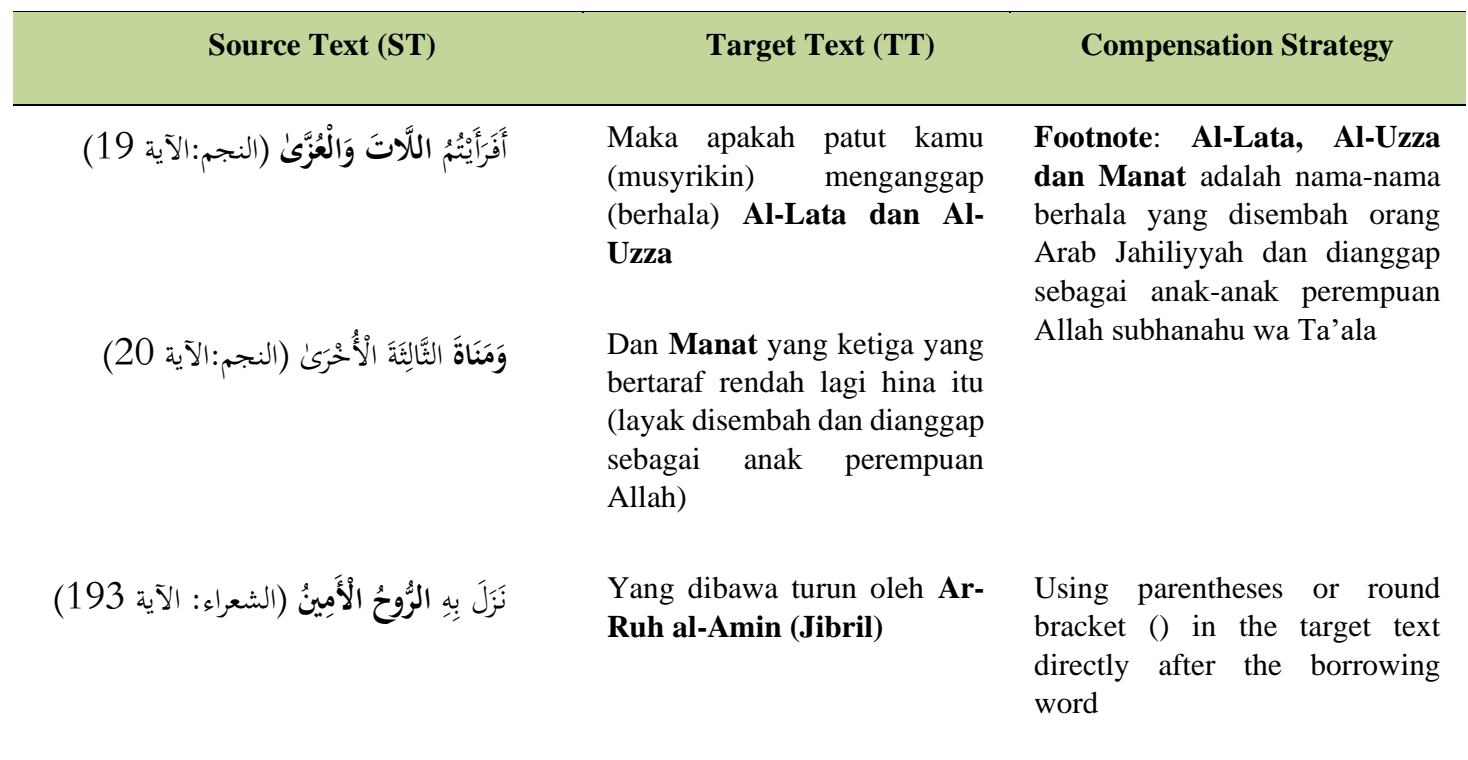


iv: Sample 4 - ST اللَّاتَ وَالْعُزََّّى TT Al-Lata dan Al-Uzza

v: Sample 5-ST مَنَّ TT Manat

- Translation approach: (Borrowing + footnote: Al-Lata, Al-Uzza dan Manat adalah nama-nama berhala yang disembah orang Arab Jahiliyyah dan dianggap sebagai anak-anak perempuan Allah subhanahu wa Ta'ala).

- Meaning: The words "Al-Lata, Al-Uzza dan Manat" are the names of some of the idols (preIslamic goddess) worshipped by the pre-Islamic Arabs https://www.almaany.com/ar/dict/ar$\underline{\text { en/ }}$ (o), its translation in Malay is tiga berhala yang disembah oleh Orang Arab Jahiliah.

- The footnote of Data 4 and 5 adequately provide the meaning of Al-Lata, Al-Uzza dan Manat in Malay language.

Based on RT, the study found that the contextual effect is high, and the processing effort is low. This is because the meaning is clearly understood thus, effects the smooth cognitive process of getting the idea of this unseen element in Malay culture. Meanwhile, the effort to process the meaning is at low limit for this translation as adequate meaning is given. In addition, the information is easily processed and at immediate rate for the target reader to understand the meaning of Al-Lata, Al-Uzza dan Manat in Malay language.

In conclusion, it is suggested that not only the borrowing approach is used to translate Al-Lata, Al-Uzza dan Manat, but also should be provided with compensation strategy. The reason is to get the idea of the meaning properly and adequately, specifically this kind of unseen element. This resulted in the optimal relevance of the translated text is successfully achieved.

\section{vi: Sample 6 - ST الرُوحُ الَََْْمِنُ TT Ar-Ruh al-Amin (Jibril)}

- Translation approach: (Borrowing + providing parentheses or round bracket () in the target text directly after the borrowing word: Ar-Ruh al-Amin (Jibril).

- Meaning: "Ar-Ruh al-Amin" refers to the Trustworthy Spirit -the angel of revelation-Jibril AS

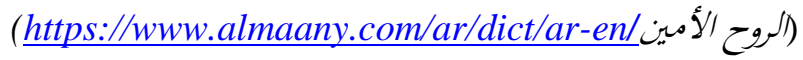

- The parentheses or round bracket () of Data 6 adequately indicate the meaning of Ar-Ruh alAmin (Jibril) in Malay language.

Based on RT, the study found that the contextual effect is high, and the processing effort is low. This is because the meaning is clearly understood thus, effects the smooth cognitive process of getting the idea of this unseen element in Malay culture. Meanwhile, the effort to process the meaning is at low limit for this translation as adequate meaning is given. In addition, the information is easily processed and at immediate rate for the target reader to understand the meaning of Ar-Ruh al-Amin in Malay language.

In conclusion, it is suggested that not only the borrowing approach is used to translate Ar-Ruh al-Amin, but also should be provided with compensation strategy. For the translation of this faith-related element, the parentheses plays its role in explaining the cultural word towards the target reader. It assists the Malay culture to have clear idea of the meaning properly and adequately. This resulted in the optimal relevance of the translated text is successfully achieved.

\section{Conclusion}

The borrowing approach which is used to translate Arasy cannot stand by itself, thus, it needs compensation strategy. However, the explanation given in the footnote is not adequate enough as to make 
the reader understands the meaning properly. This resulted in the optimal relevance of the translated text is not successfully achieved.

It is suggested that not only the borrowing approach is used to translate al-A'raf, but also should be provided with compensation strategy. The reason is to get the idea of the meaning properly and adequately, specifically this kind of unseen element. This resulted in the optimal relevance of the translated text is successfully achieved.

The study also resolves that both borrowing approach and compensation strategy assist the deeper understanding of the unseen elements in Malay culture. Providing adequate meaning of translated elements will help the target reader understand more clearly and effectively. This achieves the optimal relevancy of the translated text.

It is noted that applying borrowing approach without providing further meaning or explanation is quite hazardous and risky for the translation of faith-related elements. In this context, the parentheses play a crucial role in explaining this religious cultural type of word towards the target reader. Therefore, it is apparent that applying borrowing approach together with compensation strategy resulted in the optimal relevancy of the translated text.

In summary, when contextual effect is high and effort processing is low, the optimal relevance of the translated text is successfully achieved. However, when contextual effect is low and effort processing is high, the optimal relevance of the translated text is not successfully achieved. Thus, the researcher highly recommends the applying of borrowing approach together with compensation strategy, because it plays a significant role in order to achieve the relevancy of meaning in the translated text together with functional effect towards target culture.

On the other hand, based on the conducted analysis, the researcher asserts that the borrowing with no compensation strategy leads to ambiguity or less effective towards the target culture. Therefore, the study affirms that the higher the contextual effect of meaning is sufficiently provided, the less the effort processing is produced to understand the meaning. In this way, the relevancy of translated text can reach the optimal meaning.

It is concluded that the combination of borrowing approach and compensation strategies can help better understanding the meaning of non-existent religious cultural items in Malay culture. The relevancy of translated text can be achieved not only through borrowing as an approach, but at the same time providing adequate meaning by means of compensation strategies.

\section{References}

Abobaker Ali M. Alsaleh Brakhw \& Sharifah Fazliyaton Shaik Ismail. (2014). The Importation of the Holy Qur'an into English: Governing Factors in the Translating Process. Arab World English Journal. Special Issue on Translation No.3. 95 - 104.

Ainon Mohd \& Abdullah Hassan. (2008). Teori dan teknik terjemahan. Edisi kemas kini. Kuala Lumpur: PTS Professional Publishing Sdn. Bhd. \& Institut Terjemahan \& Buku Malaysia.

Arnida, Sulhah \& Akmal Khuzairy. (2019). Cultural Elements and Its Classification in the Qur'an: A Thematic Analysis. Penterjemahan dalam Era Digital. Prosiding Persidangan Penterjemahan Antarabangsa ke -17. Negeri Sembilan: USIM, PPM, DBP \& ITBM.

Cutting, Joan. (2002). Pragmatic and discourse a resource book for student. London: Routledge Taylor $\&$ Francis Group.

Braun, V., \& Clarke, V. (2006). Using thematic analysis in psychology. Qualitative Research in Psychology, 3(2), 77-101.

Hatim, B. (1997). Communication across Cultures: Translation Theory and Contrastive Text Linguistics. Exeter: Exeter University Press.

http://unesco.org/culture/xtrans/

(https://www.almaany.com) 
Hussein Abdul-Raof. (2001). Qur'an Translation: Discourse, Texture and Exegesis. London \& New York: Routledge Taylor \& Francis Group.

Majdi Hajj Ibrahim. (2009). al-Tarjamah bayna al-carabiyah wa al-malayuwiyah al-nazariyat wa almabadi'. Kuala Lumpur: IIUM Press.

Malay Quran Translation: Al-Kalam. (2012). Selangor: Al-Hidayah House of Quran Sdn Bhd.

Muhammad Fauzi Jumingan (2002). Penterjemahan pragmatik dalam konsep masa Arab-Melayu: Satu Analisis Teori Relevan. Pertanika J.Soc. Sci. \& Hum. 10(2): 153-164.

Newmark, P. (1988). A Textbook of Translation. UK: Prentice Hall International Ltd.

Siti Hajar Abdul Aziz. (2010). Pragmatik linguistik. Kula Lumpur: Universiti Malaya.

Qadhi, A. Y. (1999). An Introduction to the Sciences of the Qur'an. Oxford: Alden Group.

Roswani Siregar. (2016). Translation Procedures Analysis: English - Indonesian Motivational Book. IOSR Journal of Humanities And Social Science (IOSR-JHSS). Volume 21, Issue 5, Ver. 5. PP 51-57.

Sperber, D. \& Wilson, D. (1986). Relevance communication and cognition. Oxford: Basil Blackwell Ltd.

Sulhah Ramli. (2013). Aspek Pragmatik Dalam Terjemahan Huruf Al- ${ }^{c}$ atf Bahasa Arab Ke Bahasa Melayu. Bangi: UKM. Tesis Master.

Vinay, J.P. \& Darbelnet, J. (1958/1995). Comparative Stylistics of French and English: A Methodology for Translation. Amsterdam \& Philadelphia: John Benjamins. 